\title{
Antalya'nın EXPO 2016 Tecrübesi ve Organizasyon Mirasının Değerlendirilmesi
}

\author{
Tuna BATUHAN*
}

\section{Öz}

Bu çalışmada, 2016 yılında Botanik EXPO'suna ev sahipliği yapan Antalya'nın organizasyona adaylık, hazırlık ve planlama süreci ayrıntılı olarak incelenmiștir. EXPO, büyük ölçekli organizasyonlar içinde ev sahibi kente kısa, orta ve uzun vadede katkı sağlama potansiyeli ile ön plana çıkan önemli ve saygın organizasyonlardan birisidir. $\mathrm{Bu}$ çalışmada Antalya'nın EXPO tecrübesi, EXPO organizasyonunun sahip olduğu avantajlar ve EXPO'nun ev sahibi şehre bırakması beklenen diğer miraslar (altyapı ve ulaşım, parklar ve yeșil alanlar, alan ve mekan mirası, sosyal ve örgütsel kapasite ve uluslararası ilişkiler vb.) kapsamında incelenmiş ve Antalya'nın EXPO tecrübesinin olumlu ve olumsuz yönleri ayrıntılı olarak analiz edilmiştir. EXPO, ev sahibi kente önemli miraslar bırakabilecek ölçekte bir organizasyondur ve bu organizasyondaki bașarı gelecekte düzenlenmesi muhtemel benzer organizasyonların planlanmasında önemli bir referans noktasıdır. Bu çalışma kapsamında elde edilen verilerin, benzer büyük ölçekli organizasyonların adaylık ve sahnelenmesi süreçleri ile ev sahibi şehirlerin geleceğine etkilerinin planlanması aşamalarında yol gösterici olması amaçlanmaktadır.

Anahtar Kelimeler: Büyük Ölçekli Organizasyon Planlaması, EXPO, Antalya, Etkinlik Planlama, Etkinlik Mirası

\section{Evaluation of EXPO 2016 Experience and Organization Legacy of Antalya}

\section{Abstract}

In this study, the candidacy, preparation and planning process of Antalya, which hosted the Botanical EXPO in 2016, was examined in detail. EXPO is one of the important and reputable organizations that stand out in large-scale organizations with its potential to contribute to the host city in the short, medium and long term. In this study, Antalya's EXPO experience was investigated based on the advantages of the EXPO organization and other legacies expected to be left to the host city of the EXPO (infrastructure and transportation, parks and green spaces, area and location heritage, social and organizational capacity and international relations etc.) and the positive and negative aspects of the EXPO experience of Antalya were analyzed in detail. The EXPO is an organization that is able to leave significant legacies to the host city, and the success in

Özgün Araştırma Makalesi (Original Research Article)

Geliş/Received: 13.12 .2019

Kabul/Accepted: 07.02.2020

DOI: http://dx.doi.org/10.17336/igusbd.656499

* Dr. Öğr. Üyesi, Atatürk Üniversitesi, Mimarlık ve Tasarım Fakültesi, Şehir ve Bölge Planlama Böl., Erzurum, Türkiye, E-posta: tuna.batuhan@atauni.edu.tr ORCID https://orcid.org/0000-0001-7662$\underline{3405}$ 
this organization is an important point of reference in planning similar events that are likely to be organized in the future. The data obtained within the scope of this study is intended to guide the process of candidacy and staging as well as planning the effects of similar large-scale organizations on the future of the host cities.

Keywords: Large-scale organization planning, EXPO, Antalya, Event Planning, Event Legacy

\section{Giriş: Dünden Bugüne EXPO Organizasyonları ve Türleri}

Büyük ölçekli uluslararası organizasyonlardan birisi olan EXPO yerel halkın eğitilmesi, yeniliklerin paylaşılması ve uluslararası işbirliğinin teşvik edilmesini amaçlamaktadır. Ev sahipliği yapan ülke tarafından organize edilen EXPO'lara diğer ülkelerin, firmaların, uluslararası organizasyonların, özel sektör temsilcilerinin, sivil toplumun ve halkın katılımı sağlanmaktadır. Uluslararası toplumun gelişimi ve işbirliği için oluşturulan bir diyalog platformu olarak tanımlanan Expo, yerel halk için bir eğitim ve eğlence platformu; ev sahibi ülke için tanıtım ve kalkınma vesilesi; katılımcılar içinse uluslararası işbirliği ve ekonomik firsatlar anlamına gelmektedir (BIE, 2017). EXPO, ev sahibi șehirde ortaya çlkan fiziksel değișimin yanı sıra, etkinlik sonrasında şehrin yaşam kalitesi, beklentiler ve tutumlar üzerinde de olumlu değişimlere yol açmaktadır (Loscertales, 2018).

İlki 1851'de Londra'da düzenlenen EXPO'ya, daha sonraki yıllarda Paris, Viyana, Chicago ve Brüksel gibi şehirler de ev sahipliği yapmıștır. 1928'de imzalanan uluslararası bir anlaşma ile uluslararası sergilerin organize edilmesi belirli kurallara bağlanmış ve Uluslararası Sergiler Bürosu (BIE) kurulmuștur (BIE, 2017). İmzalanan anlașmayla ayrıca EXPO türleri ve her birinin düzenlenme sıklıkları belirlenmiş; ev sahibi ve katılımcıların uyması gereken yasal düzenlemeler oluşturulmuştur (BIE, 2017). BIE, en az üç hafta süren ve ticari amacı olmayan tüm uluslararası sergilerin (EXPO'ların) denetimi ve düzenlenmesinden sorumlu olan hükümetlerarası bir kuruluştur. BIE'nin temel misyonu bahsedilen organizasyonların kalitesini ve başarısını garanti etmek, bu organizasyonları düzenleyenlerin ve organizasyonlara katılanların haklarını korumak ve son olarak temel değerler olan eğitim, yenilik ve işbirliğini korumaktır (BIE, 2017). BIE'nin himayesi altında bugüne kadar 50'den fazla EXPO organize edilmiş, bu expolar milyonlarca kişi tarafından ziyaret edilmiştir. Tablo 1'de BIE öncesinde gerçekleşen tarihi Expolar, Tablo 2 'de ise BIE sonrasında gerçekleşen dünya Expoları listenenmektedir.

Tablo 1. BIE Öncesi Tarihi Expolar

\begin{tabular}{|l|l|l|}
\hline 1851 Londra, İngiltere & $\begin{array}{l}1880 \text { Melbourne, } \\
\text { Avustralya }\end{array}$ & 1905 Liege, Belçika \\
\hline 1855 Paris, Fransa & 1880 Barselona, İspanya & 1906 Milano, İtalya \\
\hline 1862 Londra, İngiltere & 1889 Paris, Fransa & 1910 Brüksel, Belçika \\
\hline 1867 Paris, Fransa & 1893 Şikago, ABD & 1913 Ghent, Belçika \\
\hline 1873 Viyana, Avusturya & 1897 Brüksel, Belçika & 1915 San Francisco, ABD \\
\hline 1876 Philadelphia, ABD & 1900 Paris, Fransa & 1929 Barselona, İspanya \\
\hline 1878 Paris, Fransa & 1904 Saint Louis, ABD & 1933 Şikago, ABD \\
\hline
\end{tabular}

Kaynak: BIE, 2017. 
Tablo 2. BIE Sonrası Dünya Expoları

\begin{tabular}{|l|l|l|}
\hline 1935 Brüksel, Belçika & 1958 Brüksel, Belçika & 1992 Seville, İspanya \\
\hline 1937 Paris, Fransa & 1962 Seattle, ABD & 2000 Hannover, Almanya \\
\hline 1939 New York, ABD & 1967 Montreal, Kanada & 2010 Şangay, Çin \\
\hline $\begin{array}{l}1949 \text { Port-Au-Prince, } \\
\text { Haiti }\end{array}$ & 1970 Osaka, Japonya & 2015 Milano, İtalya \\
\hline
\end{tabular}

Kaynak: BIE, 2017.

Günümüzde BIE'nin himayesi altında organize edilen dört tür EXPO vardır; Dünya Exposu, Özel Temalı Expolar, Bahçe Ürünleri Exposu ve Milano Exposu. Her bir EXPO kendi alanında halkı eğitmek, yeniliği paylaşmak, gelişimi desteklemek ve ortak tecrübe ve diyalog kanallarını açık tutmayı amaçlar.

Tablo 3. Bahçe Ürünleri (Botanik) Expoları

\begin{tabular}{|l|l|l|l|}
\hline Ev Sahibi Şehir, Ülke & $\begin{array}{l}\text { EXPO Alanı } \\
\text { (hektar) }\end{array}$ & $\begin{array}{l}\text { Katılmcı Ülke } \\
\text { SayıSı }\end{array}$ & $\begin{array}{l}\text { Ziyaretçi } \\
\text { Sayısı }\end{array}$ \\
\hline 2016 Antalya, Türkiye & 112 & 54 & $4,693,571$ \\
\hline 2012 Venlo, Hollanda & 66 & 38 & $2,046,684$ \\
\hline $\begin{array}{l}\text { 2006-2007 Chiang Mai, } \\
\text { Tayland }\end{array}$ & 80 & 32 & $3,848,791$ \\
\hline 2003 Rostock, Almanya & 100 & 32 & $2,600,000$ \\
\hline $\begin{array}{l}\text { 2002 Haarlemmermeer, } \\
\text { Hollanda }\end{array}$ & 140 & 30 & $2,071,000$ \\
\hline 1999 Kunming, Çin & 218 & 70 & $9,427,000$ \\
\hline 1993, Stuttgart, Almanya & 64 & 40 & $7,311,000$ \\
\hline 1992 The Hague, Hollanda & 68 & 23 & $3,355,600$ \\
\hline 1990 Osaka, Japonya & 140 & 83 & $23,126,934$ \\
\hline 1984 Liverpool, Ingiltere & 95 & 29 & $3,380,000$ \\
\hline 1983 Münih, Almanya & 72 & 23 & $11,600,000$ \\
\hline 1982 Amsterdam, Hollanda & 50 & 17 & $4,600,000$ \\
\hline 1980 Montreal, Kanada & 40 & 23 & - \\
\hline 1974 Viyana, Avusturya & 100 & 30 & $2,600,000$ \\
\hline 1973 Hamburg, Almanya & 76 & 50 & $5,800,000$ \\
\hline 1972 Amsterdam, Hollanda & 75 & - & $4,300,000$ \\
\hline 1969 Paris, Fransa & 28 & 17 & $2,400,000$ \\
\hline 1964 Viyana, Avusturya & 100 & 28 & $2,100,000$ \\
\hline 1963 Hamburg, Almanya & 76 & 35 & $5,400,000$ \\
\hline 1960 Rotterdam, Hollanda & 50 & - & $4,000,000$ \\
\hline
\end{tabular}

Kaynak: BIE, 2017

Dünya Exposu: 5 yılda bir düzenlenen ve 6 ay sure ile açık kalan Dünya Exposu ev sahibi ülkelerin devasa bahçeler veya parklar inşe ederek şehrin gelecekteki peyzajını dönüşümüne yardım eder. Daha önceki dönemlerdeki Expolardan farklı olarak, günümüz Expoları sanayideki gelişimin sergilendiği ulusal prestij kaynağı olmaktan ziyade küresel sorunlara çözüm bulmak için oluşturulan bir platform haline gelmiştir. En belirgin özelliği kentsel miras ve mimari peyzajdır. 
Özel Temalı Expolar: Özel Temalı Expolar ise belirli insani sorunlara çözüm bulmayı amaçlayan küresel etkinliklerdir. Özel Temalı Expoların eğlenceye ve entellektüel ortama dair unsurları Dünya Expolarıyla benzerlik gösterir, ancak bu organizasyonlar daha küçük çaplıdır. Bu Expolar mümkün olduğunca daha çok ülkenin ev sahipliği yapmasına ve katılımına imkan sağlamak amacıyla ortaya çıkmıştır. Özel Temalı Expolar 2 Dünya Exposu arasındaki dönemde organize edilir ve 3 ay süre ile açık kalırlar.

Bahçe Ürünleri (Botanik) Exposu: Bahçe Ürünleri Exposu BIE ve Uluslararası Bahçe Ürünleri Üreticiler Birliği'nin (Association of International Horticultural Producers) (AIPH) ortak himayesi altında organize edilen Expolardır. Bahçe Ürünleri Expoları uluslararası nitelikleri, 3-6 ay süre ile açık kalmaları, minimum 50 hektarlık alanı, milyonlarca kişinini ziyaret etmesi ve yenilik ve eğitime verdiği önemle bir anlamda Bahçe Ürünlerinin Dünya Expoları niteliğindedirler. 2016 EXPO Antalya, Bahçe Ürünleri Exposuna örnektir. Tablo 3'te bahçe ürünleri Expolarına ev sahipliği yapan șehirlerle ilgili ayrıntılar yer almaktadır.

Milano Exposu: Milano Exposu, BIE denetiminde her zaman aynı șehirde (Milano) organize edilen tek Expodur. The Triennale di Milano, tasarım endüstrisinin önemli aktörlerinin ve ziyaretçilerin biraraya geldiği önemli bir uluslararası toplantı yeridir. 2016'da düzenlenen 21. Milano Exposunun 500 bine yakın ziyaretçisi olmuştur.

Her bir EXPO kendi alanında halkı bilinçlendirmeyi, değişimi paylaşmayı, ilerlemeyi teşvik etmeyi ve diyalog ile deneyimleri aktarmayı hedeflemektedir. Çok geniş bir kitleye hitap eden ve etki sahibi kişiler, uzmanlar, sivil toplum kuruluşları ve politikacıların bir arada çalışmasına olanak veren EXPO'lar konferanslar, seminerler ve atölye çalışmaları sayesinde, kültür, eğitim ve sanat alanlarında bir buluşma noktası olmaktadır.

\section{Antalya'nın EXPO Adaylık ve Planlama Süreci}

Türkiye ve Antalya için EXPO yolculuğu 2008 yılında başlamıştır. 31 Aralık 2008'de o dönemki ismiyle Dış Ticaret Müsteşarlığı ve Orta Anadolu İhracatçılar Birliği, Uluslararası Bahçe Bitkileri Üreticileri Birliği'ne (International Association of Horticultural Producers-AIPH) üye olmuşlar ve A1 kategorisinde 2016 Uluslararası Bahçe Ürünleri (Botanik) Exposunu 2016'da Antalya'da düzenlemek üzere başvuruda bulunmuşlardır. Orta Anadolu İhracatçılar Birliği bu süreçte AIPH toplantılarında güçlü lobi faaliyetleri ile etkin bir kampanya yürütmüștür. 3-8 Ekim 2010 tarihlerinde Güney Kore'de gerçekleştirilen 62. AIPH Yıllık Toplantısı'nda Antalya'nın başvurusu onaylanmıştır. Bu onaydan birkaç ay sonra 25 Şubat 2011 tarihinde Gıda, Tarım ve Hayvancılık Bakanlığı EXPO 2016 Antalya'nın organizasyonunu koordine edecek kurum olarak belirlenmiştir. 7 Mart 2011 tarihinde de EXPO Antalya'nın gerçekleştirildiği alan AIPH tarafında onaylanmıştır, bu onayın ardından alternatif alanların belirlenmesi için AIPH delegeleri tarafindan bir ziyaret gerçekleştirilmiştir. 7 Nisan 2011 tarihinde Türkiye Cumhuriyeti Başbakanı imzasıyla Uluslararası Sergiler Bürosu'na (BIE) bir garanti mektubu gönderilmiştir. Tüm bu gelişmelerin ardından 22-23 Kasım 2011 tarihlerinde gerçekleştirilen 151. BIE Genel toplantısında tek aday olan Antalya'nın EXPO $2016 \mathrm{ev}$ sahipliği tescillenmiş, BIE bayrağı Türkiye'ye devredilmiștir. 
Tuna Batuhan, “Antalya'nın EXPO 2016 Tecrübesi ve Organizasyon Mirasının Değerlendirilmesi”, İstanbul Gelişim Üniversitesi Sosyal Bilimler Dergisi, 7 (2), Ekim 2020, ss. 281-298.

Tablo 4. EXPO Antalya 2016 Tarihsel Süreç

\begin{tabular}{|c|c|}
\hline 31 Aralık 2008 & $\begin{array}{l}\text { Türkiye'nin AIPH'ye üye olması ve 2016'da EXPO'nun Antalya'da } \\
\text { düzenlemesi için başvurunun yapılması }\end{array}$ \\
\hline 3-8 Ekim 2010 & Antalya'nın bașvurusunun onaylanması \\
\hline 25 Şubat 2011 & $\begin{array}{l}\text { Gıda, Tarım ve Hayvancılık Bakanlı̆̆ı'nın EXPO } 2016 \text { Antalya'yı koordine } \\
\text { edecek kurum olarak belirlenmesi }\end{array}$ \\
\hline 7 Mart 2011 & EXPO Antalya alanının AIPH tarafindan onaylanması \\
\hline 7 Nisan 2011 & BIE'ye garanti mektubunun gönderilmesi \\
\hline 22-23 Kasım 2011 & Antalya'nın EXPO 2016 ev sahipliğinin tescillenmesi \\
\hline 10 Kasım 2012 & $\begin{array}{l}\text { EXPO Yasası'nın TBMM'den geçmesi } \\
\text { EXPO Antalya Ajansı'nın kurulması }\end{array}$ \\
\hline Ağustos 2013 & EXPO alanında inşaat çalışmalarının başlaması \\
\hline Nisan 2015 & EXPO 2016 Antalya Genel Sekreteri'nin Atanması \\
\hline Aralık 2015 & Katılımcıların EXPO alanında inşaat çalışmalarına başlaması \\
\hline 12 Ocak 2016 & EXPO Antalya'nın Cumhurbaşkanlığı himayesine alınması \\
\hline 22 Nisan 2016 & EXPO Antalya'nın resmi açılış töreninin gerçekleştirilmesi \\
\hline 23 Nisan 2016 & EXPO Antalya'nın halka açılması \\
\hline 29 Ekim 2016 & Uluslararası Yarışmalar Ödül Töreni \\
\hline 30 Ekim 2016 & EXPO Antalya'nın resmi kapanış töreninin gerçekleştirilmesi \\
\hline Kasim 2016 & BIE tarafından alanda son denetimlerin yapılması \\
\hline Aralık 2016 & AIPH tarafindan alanda son denetimlerin yapılması \\
\hline
\end{tabular}

Kaynak: T.C. Cumhurbaşkanlığı, 2016.

Bu gelişme sonrasında süreç daha hızlı ilerlemiş, kurumsal ve altyapı ile ilgili faaliyetler hız kazanmıștır. 10 Kasım 2012'de 6358 sayılı EXPO 2016 Antalya Kanunu yayımlanmış ve Gıda, Tarım ve Hayvancılık Bakanlığı bünyesinde EXPO Antalya Ajansı kurulmuştur. 2013 yılının Ağustos ayından itibaren EXPO alanında inşaat çalışmaları bașlamış ve 22 Nisan 2016 tarihinde resmi bir törenle EXPO Antalya ziyaretçilerine kapılarını açmıştır. EXPO Antalya 2016'nın tarihsel gelişim süreci Tablo 4'te ayrıntılı olarak verilmiştir.

\section{EXPO Antalya'nın Teması ve Amaçları}

“Gelecek Nesiller İçin Yeşil Bir Dünya” vizyonu ile yola çıkan EXPO Antalya 2016, hedef kitle olarak gençleri ve çocukları belirleyerek; çevre bilincinin geliştirilmesi, duyarlılığının arttırılması ve yeni nesillere aktarılmasını hedeflemiștir (T.C. Cumhurbaşkanlığı, 2016). EXPO Antalya 2016, Türkiye'nin ev sahipliği yaptığı ilk EXPO olması bakımından da önemlidir. EXPO 2016 Antalya'nın ana teması, "Geleceği Yeşillendirme" iddiasıyla "Gelecek Nesiller İçin Yeşil Bir Yaşam” felsefesi ile "Çiçekler ve Çocuklar" olarak belirlenmiştir (T.C. Cumhurbaşkanlığı, 2016). Ana temanın yanı sıra, "Tarih, Biyoçeşitlilik, Sürdürülebilirlik ve Yeşil Şehirler" gibi alt temalar da belirlenerek EXPO Alanı ve katılımcı sergilerinin belirlenen temalara uygun şekilde tasarlanması amaçlanmıştır.

EXPO Antalya, uluslararası işbirliği, kültürel ve ekonomik programlar aracılığıyla, uluslararası bahçecilik ve tarım alanlarındaki gelişmeleri takip etmeyi, teşvik etmeyi ve tecrübe paylaşımını amaçlamaktadır (T.C. Cumhurbaşkanlığı, 2016). Uluslararası 
bahçecilik sergilerinin ortak amaçları olarak sıralanabilecek bu unsurların yanı sıra EXPO Antalya vasitasiyla:

Türkiye'nin katılımcı ülkelerle ikili ilişkilerine katkıda bulunmak,

Daha fazla yeşil alan, yeni iş olanakları ve şehir altyapısına yeni yatırımlar sayesinde yaşam kalitesini arttırmak,

Antalya'da eko turizmi desteklemek ve tanitmak,

Türk bahçecilik sektörünün potansiyelini yeni tanıtım ve işbirliği fırsatlarıyla desteklemek,

Türkiye'nin biyoçeşitliliğinin zenginliğini dünyaya tanıtmak,

Bilgi ve eğlence yoluyla çocukları çevre konularında eğitmek,

Çevre konularında ve sürdürülebilirlikte farkındalığı arttırmak amaçlanmıştır.

\section{EXPO Antalya Organizasyon Yapısı}

10 Kasım 2012'de yayımlanan kanunla Gıda, Tarım ve Hayvancılık Bakanlığı bünyesinde kurulan EXPO Antalya Ajansı etkinliklerinin planlanması, düzenlenmesi ve yönetilmesinden sorumlu olan kurumdur. 8 Mayıs 2013 tarihli ve 28641 sayılı EXPO 2016 Antalya Ajansının Çalışma Esasları Hakkında Yönetmelikle, Ajansın çalışmasına ilişkin usul ve esaslar düzenlenmiștir. EXPO Antalya Ajansı geniş yetkilere sahip olan Yönetim Kurulu ile EXPO Konseyi, Genel Sekreterlik ve Ofisten oluşmaktadır.

EXPO Yönetim Kurulu: EXPO Antalya'nın karar organı olan EXPO Yönetim Kurulu, EXPO 2016 Antalya'nın hazırlığı, düzenlenmesi ve sonuçlandırılması ile ilgili her türlü iş ve işlemlerde yetkilidir. EXPO Yönetim Kurulu'nun başkanlığını Gıda, Tarım ve Hayvancılık Bakanı yapmaktadır. Kurulun diğer üyeleri ise en az genel müdür seviyesinde bakanlık temsilcileri (Dışişleri Bakanlığı, Ekonomi Bakanlığı, Kültür ve Turizm Bakanlığı, Gıda Bakanlığı) ile yerel kurumların temsilcilerinden (Antalya Valiliği, Antalya Belediye Başkanlığı, Antalya Sanayi ve Ticaret Odası ve Antalya Ziraat Odası) oluşmaktadır.

EXPO Konseyi: EXPO Konseyi, EXPO Kanunu'nun 5inci maddesinde adı geçen kurumlarca görevlendirilen elli dört üyeden oluşur. EXPO Konseyi'nin başkanı Antalya Valisidir. EXPO Konseyi, EXPO 2016 Antalya'nın başarılı bir şekilde gerçekleștirilmesi amacıyla gerekli gördüğü tavsiye kararlarını alır, hazırlık çalışmaları kapsamında yıllık program, bütçe, yurt içi ve yurt dışı tanıtım faaliyetleri ile gerekli görülen diğer konularda görüşlerini ve tavsiyelerini bildirir, Yönetim Kurulu ile Genel Sekreterliğin çalışmalarını izler.

Genel Sekreterlik: EXPO 2016 Antalya Ajansının sekretaryasını yürütmek ve bu kapsamda verilen görevleri yerine getirmek üzere Antalya'da kurulan Genel Sekreterlik, Ajansın iş ve işlemlerinin yürütülmesinden sorumlu uygulama birimidir. Genel Sekreterlik, EXPO 2016 Antalya ile ilgili bütün faaliyetlerin Yönetim Kurulu tarafından belirlenen esaslar çerçevesinde programlanmasından, yürütülmesinden ve koordinasyonundan sorumludur.

EXPO Ofisi: Ofis ise, Genel Sekretere bağlı olarak Yönetim Kurulu ve EXPO Konseyinin sekretarya çalıșmalarını yürüten ve Bakanlık bünyesinde Ankara'da kurulan Ajans birimidir.

Genel Sekteterliğin her türlü uygulamasının denetimi Gıda, Tarım ve Hayvancılık Bakanlığı'na bırakılmıştır. Başka bir ifade ile EXPO 2016 Antalya'yı koordine edecek kurum olarak belirlenen bakanlık, aynı zamanda denetleyici konumundadır. Bakanlığın yanı sıra Antalya Valiliği ve Antalya Büyükşehir Belediyesi de süreçte söz sahibi olmuştur. Antalya Valiliği tarafından hazırlanan EXPO 2016 Yönergesi kapsamında EXPO Meclisi ve EXPO İcra Kurulu oluşturulmuştur. Antalya Valisi'nin başkanlık ettiği mecliste birçok kurumun temsilcileri yer almıştır. 


\section{EXPO Antalya'nın Mirası}

EXPO Antalya 2016, 23 Nisan-30 Ekim 2016 tarihleri arasında ziyaretçilerine kültürel ve görsel bir şölen sunmuştur. "Çiçekler ve Çocuklar" temalı oyun alanları ve çocuk etkinlik alanları tüm alana yayılmış; EXPO temasına uygun şekilde katılımcıların bahçelerinde çocuklar için özel aktivite alanları sunulmuştur. EXPO Antalya'da öne çıkan diğer unsurlar kültürel programlar, konserler, dans gösterileri ve tiyatro oyunları olmuştur. Ayrıca farklı konu başlıklarında birçok konferans, seminer, ulusal gün kutlamaları ve özel etkinlikler gerçekleștirilmiştir (T.C. Cumhurbaşkanlığı, 2016). EXPO Antalya kapsamında gerçekleştirilen organizasyonlar Tablo 5 'te listelenmiştir.

Tablo 5. EXPO Antalya'da Gerçekleștirilen Organizasyonlar

\begin{tabular}{|r|l|}
\hline 129,482 & Kültürel program ve etkinlik \\
\hline 116,213 & Çocuklar için aktivite ve etkinlik \\
\hline 85,934 & Eğitim faaliyeti ve Çalıştay \\
\hline 13,144 & Sanatsal ve kültürel performans \\
\hline 110 & Seminer, toplantı, akademik çalıştay, forum, seminer, panel \\
\hline 99 & Uluslararası katılımcılar tarafından düzenlenen özel organizasyonlar \\
\hline 26 & Milli Gün kutlaması \\
\hline
\end{tabular}

Kaynak: T.C. Cumhurbaşkanlığı, 2016

EXPO Antalya'yı resmi rakamlara göre 4,693,571 kişi ziyaret etmiştir (T.C. Cumhurbaşkanlığl, 2016). Ziyaretçilerin yüzde 71'i Türk, geriye kalan yüzde 29'luk kısmı ise yabancı ziyaretçilerden oluşmaktadır. Ana teması "Çiçekler ve Çocuklar" olan EXPO Antalya'nın ziyaretçilerinin yüzde 33'ü çocuklardan (0-13 yaş arası); yüzde 64'ü yetişkinlerden ve yüzde 3'ü ise engellilerden oluşmaktadır. EXPO kapsamında organize edilen konserler ve diğer etkinlikler EXPO alanı içerisinde gerçekleştirildiği için, bu etkinliklere katılan her bir kişi EXPO ziyaretçisi olarak değerlendirilmiştir. Bilet satışlarına bakıldığında, biletlerin yüzde 58'lik kısmının ana kapıdan satıldığı; internet üzerinden satışların sadece yüzde 10 oranında olduğu görülmektedir (T.C. Cumhurbaşkanlığı, 2016). Bu rakamlar EXPO ziyaretlerinin planlamasının önceden yapılmadığı izlenimini vermektedir. Biletlerin yüzde 92 oranında günlük olarak satın alınması ve sezonluk bilet satışlarının sadece yüzde 8 olması da bu tespiti destekler niteliktedir.

EXPO 2016 Antalya'nın kapanışında yayınlanan ortak deklerasyonla, EXPO katılımcılarının EXPO teması ve alt temalarıyla ilgili konulardaki ortak kaygıları ve gelecekteki taahhütleri dile getirilmiştir. Deklerasyonda, "Gelecek Nesiller İçin Yeşil Bir Dünya” felsefesi çerçevesinde, doğa sevgisini gelecek nesillere aktarmak için birçok faaliyet gerçekleştirildiği ifade edilmektedir. EXPO Antalya sayesinde sürdürülebilirlik ilkesinin hayata geçirilmesi ve biyolojik çeşitliliğinin korunması hedeflerine ulaşmak adına farkındalığın arttırıldığı vurgulanmakta; insanlığın ancak sağlıklı bir çevre, doğa dostu üretim, sürdürülebilirlik ve paylaşım yoluyla en iyi yaşam koşullarını yaratabileceğinin altı çizilmektedir.

EXPO Antalya sonuç deklerasyonunda gelecek hedefleri "Tarih, Biyoçeşitlilik, Sürdürülebilirlik ve Yeşil Şehirler" alt başlıklarında açıklanmıștır (T.C. Cumhurbaşkanlığı, 2016). İlk hedef, insan faaliyetlerinin doğa ile uyumlu hale getirilmesi olarak 
belirlenmiştir. Biyoçeşitliliğin ve doğal çevrenin korunmasının tüm ülkelerin önceliği olması gerektiğini ifade eden deklerasyon; doğaya saygı gösterilmesi ve şehirlerde yeşil alanların arttırılması ilkelerini benimsemektedir. Deklerasyonun sonuç bölümünde, çocuklar ve doğanın insanlığın geleceği olduğu vurgusu yapılmaktadır. Dünyadaki tüm olumsuz gelişmelere ve tehditlere rağmen, çocuklara ve doğaya verilen önemin arttırılacağl; bilgi ve tecrübenin daha geniş bir ișbirliği ile paylaşılacağı ifade edilerek "gezegenimizin geleceği için umutlu olmaya" devam edileceği ifade edilmektedir.

Antalya'nın tecrübesi, EXPO'nun diğer büyük ölçekli organizasyonlara kıyasla sahip olduğu avantajlar (Wilson, 2018) bağlamında değerlendirilebilir. İlk olarak EXPO diğer büyük ölçekli sportif organizasyonların aksine (Olimpiyatlar, Dünya Kupası gibi), organizasyondan sonra atıl durumda kalma riski bulunan ciddi tesis ve stadyum yatırımlarını gerektirmemektedir. Bu durum, ev sahibi șehrin organizasyon üzerinde daha fazla kontrol sahibi olmasını sağlamakta; bu kontrol sayesinde daha kalıcı değerlere sahip bir organizasyon tasarlamaya imkân vermektedir. Ancak, Antalya'nın tecrübesi göstermektedir ki, EXPO organizasyonunun avantajı olarak görülen atıl tesislerin ortaya çıkmaması durumu EXPO Antalya'da bir avantaja dönüşmemiş; tam aksine geleceğe devredilen önemli bir sorun alanı olmuştur. EXPO Antalya alanının mevcut durumda atıl kalması ve gelecek kullanımının halen belirlenememiş olması, organizasyon mirasının doğru şekilde planlanamadığını göstermektedir.

İkinci olarak, Olimpiyatlar ve Dünya Kupası gibi organizasyonların odak noktasını sportif etkinlikler ve bu etkinliklerin gerçekleştiği stadyumlar oluşturmakta; etkinlik için o şehirde bulunan ziyaretçiler şehir yerine müsabakaları tecrübe etmektedirler (Wilson, 2018). Olimpiyat ve Dünya Kupası gibi organizasyonlar şehirde bulunan ziyaretçilerden önce ve onun ötesinde sportif etkinliği medyadan takip eden izleyicilere odaklanmaktadır. Sportif organizasyonlara kıyasla medyadaki görünürlügü daha az olan EXPO'nun odak noktası ise etkinlik için şehirde bulunan ziyaretçilerdir; organizasyon tamamen ziyaretçilere hizmet etmeyi ve onları memnun etmeyi amaçlar (Wilson, 2018). Ancak, EXPO Antalya'nın açık kaldığı sürede ortaya çıkan aksaklıklar ziyaretçilerin deneyimini olumsuz yönde etkilemiştir. EXPO alanının şehirden uzak olması ve alana erișimi kolaylaștırması beklenen raylı sistemin EXPO alanı açıldığında etkin olarak çalışmaması, bilet fiyatlarının yüksek olması (sonrasında belirli kampanyalarla fiyatlar indirilmiştir), EXPO açıldıktan sonra da alanda inşaatın devam etmesi gibi nedenler de EXPO'nun istenilen olumlu etkiyi yapamamasına neden olmuştur.

Üçüncü olarak, sportif organizasyonların başlıca mirası olan stadyumların ayırt edici unsurları ve özgünlükleri sınırlı olduğundan, organizasyonun sembolü haline gelebilmeleri daha zor iken; EXPO tecrübesinin ev sahibi şehirlerle özdeşleşen sembolik yapılar üretmesi daha yaygındır (Wilson, 2018). EXPO için inşa edilen bazı sembolik yapılar, ev sahibi șehrin ziyaretçiler gözünde markalașması, küresel bir şehir olarak algılanması ve kimlik kazanması işlevini de görebilir. EXPO sonrası șehirlere marka değeri katan ve o şehirle sembolleșen yapılar arasında Eyfel Kulesi (Paris), Atomium (Brüksel), Uzay İğnesi (Seattle), Unisphere (New York) ve Güneş Kulesi (Osaka) sayılabilir. EXPO Kulesi de EXPO Antalya'nın sembolik yapılar mirası olarak değerlendirilebilir. EXPO Antalya'nın simgesi haline gelmiş olan 100,7 metre yüksekliğindeki EXPO Kulesi, ziyaretçilere EXPO sergi alanı ve çevresini gözlemleme imkanı sunmuştur. EXPO Kulesi, Dünya Mimarlık Festivali'nde "En İyi Tamamlanmış Sergilenen Yapı" kategorisinde finale kalmış; Engineering News-Record tarafından Dünyanın En İyi Yapıları 2017 ödül töreninde ise 'Dünyanın En İyi Kültürel Yapısı' seçilmiștir (Anonim, 2017a). Ancak EXPO Kulesi'nin sembolik niteliğinin Antalya şehri ile özdeşleşmiş olduğunu söylemek güçtür. Bunun temel nedeni, EXPO Kulesi'nin şehir hayatının dışında ve turistlerin ilgi alanından uzak bir konumda olan EXPO Alanının içerisinde bulunmasıdır. EXPO alanının turistik bir çekim alanına dönüşememiş olması, EXPO Kulesi'nin de sembolik niteliğini azaltmaktadır. 
Son olarak, yerel halkın Olimpiyatlar, Dünya Kupası gibi sportif etkinliklere doğrudan katılımları sınırlı iken; yerel halk için daha erişilebilir olan EXPO, yerel katılıma daha fazla imkân sunmaktadır (Wilson, 2018). Ancak EXPO Antalya, yerel halkın etkinliğe katılımı konusunda da başarılı olamamıştır. Yerelde en çok ortaya çıkan şikayet EXPO Antalya'nın tanıtımının doğru ve etkin bir şekilde yapılamadı̆̆ı, halkla ilişkiler kısmının çok kötü yönetildiğidir. Antalya yerel halkının bile gerçekleştirilecek etkinliklerden haberdar edilmediği, bu nedenle dünyaca ünlü birçok sanatçının konserlerini birkaç yüz kişiye vermek zorunda kaldıkları; Antalya yerel halkının birçok etkinlikten ertesi gün gazete, tv ve internet yayınlarıyla haberdar olduğu ifade edilmektedir (Anonim, 2016a). $\mathrm{Bu}$ süreçte etkinliklere katılımın arttırılmasında önemli rol oynayabilecek olan tur operatörleri ve otellerin de etkinliklerin duyurulmasında etkin kullanılmadığı ve hatta etkinlik programının gizli tutulduğu ifade edilmektedir. Akdeniz Turistik Otelciler ve İşletmeciler Birliği (AKTOB) Başkanı Yusuf Hacısüleyman, EXPO etkinliklerinin ve programının kendilerine iletilmesini istediklerini, ancak yasak olduğu gerekçesiyle herhangi bir bilgilendirmenin yapılmadığını ifade etmiștir (Anonim, 2016b). Yerel aktörlere etkinliklerin duyurulmamasının yanında bu aktörler EXPO planlama sürecine de dahil edilmemişlerdir. Özellikle turizm sektörü temsilcileri, sivil toplum, yerel belediyeler, tur acenteleri ve otellerin sürece dahil edilmesi daha yüksek katılımlı etkinliklerin gerçekleștirilmesine vesile olabilirdi, ancak EXPO Antalya organizasyon sorumluları bu firsatı etkin şekilde kullanamamıştır. Antalya Tanıtma Vakfı (ATAV) Başkanı Nizamettin Şen,"Üzülerek söylüyorum ama EXPO 2016'yı defolu bir organizasyon haline getirdiler" diyerek süreci eleştirmektedir (Anonim, 2016c). 8 milyon ziyaretçinin beklendiği bir organizasyonun planlanması ve tanıtımı süreçlerinde yerel aktörlerin etkin şekilde kullanılmaması, sürece dahil edilmemesi, bilgilendirilmemesi ve sürecin dışında tutulması organizasyonun başarısını olumsuz yönde etkilemiştir.

Katılımın etkin işletilemediğinin bir diğer örneği ise EXPO sembol çiçeğinin belirlenmesi sürecidir. EXPO'nun sembol çiçeğini belirlemek için EXPO Antalya web sitesinde 14 Şubat 2013'te başlayan oylamalar, 7 Mart 2013 Saat 23:59 tarihinde sona ermiștir. Yapılan oylamada yabani karanfil 11 bin 166, şakayı 5 bin 346, papatya bin 903 , menekşe ise 435 oy almış ve yabani karanfil EXPO Antalya sembol çiçeği olarak belirlenmiștir (EXPO Antalya Web Sayfası). Ancak, o dönem Gıda, Tarım ve Hayvancılık Bakanı olan Mehmet Mehdi Eker, Antalya'da düzenlediği basın toplantısıyla şakayık çiçeğinin EXPO Antalya'nın sembol çiçeği olarak belirlendiğini duyurmuştur. Antalya'da üretilen ve yurt dışına ihraç edilen karanfil yerine, Antalya ile ilgisi olmayan bir kış çiçeği olan şakayık bitkisinin sembol çiçek olarak belirlenmesi katılım süreciyle ilgili ironik bir durum oluşturmaktadır.

Yerelden destek alınmamasının en önemli sebebi olarak yerel kurum ve kurulușlardan ziyade merkezi hükümetin EXPO Antalya planlama sürecini kontrol etmiș olması gösterilebilir. Bu durum planlama sürecinde hızlı kararlar alınmasını sağlamıș olabilir, ancak alınan bu kararların etkinliği ve uygulanabilirliği tartışma konusudur. Yerel ve merkezin planlama sürecindeki rolunün bir diğer yansıması da EXPO Antalya Ajansı yönetiminde sıkça yapılan değişikliklerdir. EXPO Antalya Kanunu'nun kabul edilmesinin ardından 11 Kasım 2012'de EXPO 2016 Antalya Genel Sekreteri olarak, dönemin Bakanı Mehdi Eker'in eski özel kalem müdürü Selami Gülay atanmıştır. Günay, 22 Ocak 2015 tarihinde sosyal medya hesabından yaptığı paylaşımla, Genel Sekreterlik görevinden istifa ettiğini duyurmuş (Anonim, 2015a); yerine genel sekreter yardımcısı Haşmet Suiçmez atanmıştır. Suiçmez göreve başladıktan 11 ay sonra, EXPO'nun açlışına dört ay kala Bakanlık tarafından görevden alınmış ve yerine Kazım Aydın getirilmiştir. Son olarak, Aydın 14 Haziran 2016'da genel sekreterlik görevinden ayrılmış ve yerine genel sekreter yardımcısı Fırat Işık atanmıştır. Ajans Genel Sekreterinin sürekli değişmesi her yeni gelen yöneticinin süreci baştan öğrenmesini gerektirdiği için zaman kaybına yol açmış; aynı 
zamanda yapılması gereken işlerde devamlılığın sağlanmasını engellemiştir. 4 yıllık süre içerisinde 4 kez genel sekreter değișikliğine gidilmiş olması, hem sürecin iyi yönetilemediğini göstermiş, hem de örgütsel mirasın oluşamamasına neden olmuştur.

EXPO'nun diğer büyük ölçekli organizasyonlara kıyasla sahip olduğu diğer avantaj (Wilson, 2018) ise, EXPO organizasyonunun alan seçimindeki esnekliği sayesinde ev sahibi şehre etkinlik sonrası çok kullanımlı alanlar tasarlayabilme imkânı sunmasıdır. EXPO Antalya'nın bu kapsamda değerlendirilmesi “Alan ve Mekan Mirası” başlığı altında ayrıntılı olarak yer almaktadır. Son olarak EXPO'nun diğer büyük ölçekli organizasyonlara kıyasla tek dezavantajı, medyadaki görünürlüğün daha az olmasıdır (Wilson, 2018). EXPO Antalya kapsamında gerçekleştirilen etkinliklerin yerel medyada dahi yer alamaması, EXPO'nun medya görünürlüğünü daha da azaltıcı bir etki yapmıştır.

EXPO'nun ev sahibi şehre bırakacağı diğer miraslar altyapı ve ulaşım, parklar ve yeşil alanlar, alan ve mekan mirası, sosyal ve örgütsel kapasite ve uluslararası ilişkiler başlıklarında incelenebilir (Wilson, 2018).

\subsection{Altyapı ve Ulaşım}

EXPO Antalya'nın olumlu miraslarının başında kent altyapısına yapılan yatırımlar ve EXPO alanı sayılabilir. EXPO vesilesiyle Antalya'nın uzun vadede gelişimine hizmet edecek turizm, altyapı ve ulaşım yatırımları gerçekleştirilmiş; yeni yeşil alanlar oluşturulmuş, kanalizasyon sistemleri yenilenmiş, yeni yollar, köprüler ve raylı sistem inşa edilmiştir. EXPO Antalya sayesinde gerçekleştirilen altyapı yatırımları ile EXPO alanının erişilebilirliği kolay hale gelmiş ve Antalya'nın altyapısını önemli ölçüde geliştirilmiştir. Temel altyapı yatırımları şu şekilde listelenebilir (T.C. Cumhurbaşkanlı̆̆g, 2016): inşası,

Antalya Şehir Merkezi ile Belek ilçesi arasındaki 30 kilometrelik yolun yeniden

Antalya Şehir Merkezi ile EXPO Alanı arasındaki 18,7 km'lik tramvay,

Aksu bölgesinin EXPO Sitesi ile Lara-Kundu ilçeleri arasındaki 14 km'lik kanalizasyon sistemi iyileştirildi.

EXPO Alanının doğu ve batısındaki Aksu ve Tehnelli nehirleri, EXPO Alanında ve bölgede su taşkınlarını önlemek için iyileştirildi. Bu iyileştirme bölgedeki su yönetimi ve tarımsal alanların verimliliğinin arttırılması açısından da önemlidir.

EXPO, ev sahibi şehrin etkinlik için gereken kamu desteğini kazanmasını kolaylaştıran, süreçteki bürokratik tıkanıklıkları en aza indiren ve sonuçta şehrin geleceği için değerli bir altyapı mirasının ortaya çıkmasını sağlayan önemli bir araç olarak görülebilir. EXPO vesilesiyle yapılan altyapı ve ulaşım yatırımlarının șehrin toplu ulaşım, havaalanı ve karayolu gelişimini iyileștirmesi ve şehrin uzun vadeli ihtiyaçlarını karşılaması beklenir, ancak EXPO Antalya örneğinde yapılan yatırımların şehrin gelecek hedefleriyle tam olarak örtüştüğü söylenemez.

\subsection{Parklar ve Yeşil Alanlar}

Parklar ve yeşil alanlar, EXPO sonrasında ev sahibi şehre kalan önemli miraslardan bir diğeridir. EXPO Antalya alanı șehrin yeşil alan rezervine katkıda bulunan, gelişime açık bir proje olarak EXPO'nun kalıcı mirasları arasında yer almaktadır. 112 hektarlık EXPO alanında 7,15 hektar büyüklüğünde EXPO Gölü, 36,176 m2 açık bahçe alanı (uluslararası katılımcılar için), 11,655 m2 sergi alanı (ulusal katılımcılar için) ve 3000 m2 kapalı bahçe alanı bulunmaktadır (T.C. Cumhurbaşkanlığı, 2016). Kalıcı bir alan olarak inşa edilen EXPO Alanı, bahçecilik ve tarım sektörünün gelecekteki gelişimi için temel oluşturabilecek bir miras olarak görülebilir. EXPO alanının içerisinde bulunan 
tesislerin çevre bilincini artırmak, tarımsal sorunları tartışmak ve çözüm üretmek için biraraya gelinebilecek önemli bir platform olarak değerlendirilmesi; bu alanlarda teknoloji ve eğitim merkezi olarak kullanılması da hedeflenmektedir. Ancak, EXPO Antalya alanının bu amaçlara hizmet etmesini sağlayacak girişimler henüz gerçekleşmiș değildir.

EXPO Alanı içerisinde yer alan EXPO Gölü de, EXPO Antalya'nın ekolojik mirasının önemli unsuru olarak değerlendirilebilir. EXPO Gölü'nde bir sulak alan ekosistemi oluşturularak alana su bitkileri, 11 balık türü ile birkaç kurbağa türü, kaplumbağa ve diğer hayvanlar konulmuştur (T.C. Cumhurbaşkanlığl, 2016). Bu sulak alan ekosistemin, biyoçeşitliliğin ve sürdürülebilirliğin korunmasına dikkat çekerek çevre bilincinin arttırmasını ve genç kuşaklara ulaştırmasını hedeflemektedir. EXPO Antalya Sonuç deklerasyonunda, çevre bilincini artırmak ve gelecek nesillere aktarmak adına, her yeni doğan bebek için bir ağaç dikilmesini amaçlayan "Yenidoğan Ormanları Projesi" kapsamının Türkiye'de genişletileceği ifade edilmiş; bu projenin diğer ülkeler tarafından kabul edilmesi çağrısı yapılmıştır (T.C. Cumhurbaşkanlığı, 2016). Ancak, Türkiye'de bazı belediyeler ve kamu kurumları tarafından uygulanan bu projenin kapsamının genişlediği ve tüm ülkede uygulandığı söylenemez.

\subsection{Alan ve Mekan Mirası}

EXPO alanı içerisinde yer alan binalar ve tesisler de organizasyon mirası olarak değerlendirilebilir. EXPO alanında inşa edilen Kongre Merkezi EXPO süresince birçok uluslararası toplantı, panel, konferans, konser, sergi ve gösteriye ev sahipliği yapmıștır. Bununla birlikte, çeșitli konser ve performanslara ev sahipliği yapan EXPO Meydanı; EXPO Gölü'nde gerçekleștirilen su ve ışık şovlarını izlemek için oluşturulan Şakayık Teras; çocuklara eğlence, eğitim etkinliği ve atölye çalışması imkanlarının sunulduğu çocuk adası ile sanat ve sergi salonu, büyük ve küçük amfi tiyatrolar ve diğer açık etkinlik alanları da EXPO alanında bulunan organizasyon mirası unsurları arasında yer almaktadır (T.C. Cumhurbaşkanlığı, 2016). EXPO alanında yer alan bina ve tesislerin tamamı Şekil 1'de ayrıntılı olarak listelenmiștir.

EXPO Antalya'nın 30 Ekim 2016 tarihinde kapanmasının ardından, 23 Kasım 2016'da Paris'te gerçekleşen BIE 160. Genel Kurulu'nda Türk heyeti tarafından EXPO Antalya'nın final sunumu gerçekleştirilmiş ve Türkiye'nin raporu BIE tarafından onaylanmıştır (BIE, 2017b). Türkiye'nin raporunun onaylanmasının ardından EXPO'nun tasfiye işlemleri ve devralınması ile ilgili süreç başlamış; EXPO Kanunu'nun 15. Maddesi gereği tasfiye işlemlerinin 30 Haziran 2017'ye kadar tamamlanması hedeflenmiştir (Anonim, 2017b). Bu kapsamda EXPO 2016 Antalya, Özelleştirme Yüksek Kurulu tarafından 18 Nisan 2017'de Gıda, Tarım ve Hayvancılık Bakanlığına devredilmiş ve özelleştirme işlemlerinin 31 Aralık 2022 tarihine kadar tamamlanacağı belirtilmiştir (Anonim, 2017c). EXPO 2016 alanının özelleștirilmesiyle ilgili profesyonel yatırımcı bulabilmek amacıyla 7 Kasım 2017'de Ankara'da bir çalıștay düzenlenmiștir (Özelleștirme İdaresi Bașkanlığı, 2017). EXPO alanının özelleștirilmesi kapsamında, 13 Aralık 2017 tarihinde Resmi Gazete'de yayınlanan projeye göre EXPO alanının mevcut durumunun korunarak ekonomiye kazandırılması amacıyla "Ticaret-turizm alanı, fuar, panayır ve festival alanı, teknik altyapı alanı, resmi kurum alanı (karakol), su yüzeyi (kanal) ve yol" olarak planlanmış; ancak Antalya milletvekillerinin girișimleriyle proje askiya alınmıștır (Anonim, 2018a). 


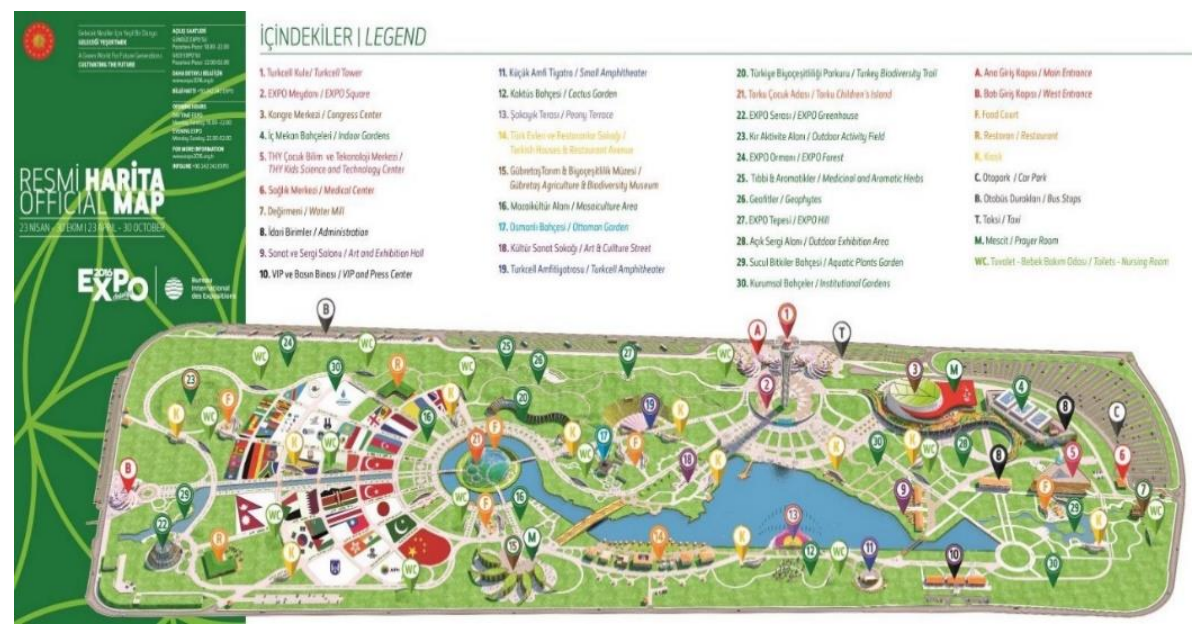

Kaynak: BIE, 2017

\section{Şekil 1. EXPO Alanında Yer Alan Bina ve Tesisler}

1 Haziran 2018 itibariyle Gıda Tarım ve Hayvancıllk Bakanlığı Antalya İl Müdürlüğü yönetimine devredilen EXPO alanında, devir sonrası temizlik ve bakım işleri yapılmaya başlanarak alanın yeniden canlandırılması için altyapı çalışmalarına hız verilmiş ve EXPO alanına girişler 15 Haziran 2018 itibariyle ücretsiz hale getirilmiştir (Anonim, 2018b; Anonim, 2018c). Sonrasındaki dönemde EXPO alanının durumu sürüncemede kalmaya devam etmiş; alanda bulunan bahçeler, sergi alanları ve bitkiler bakımsızlıktan çürümeye başlamıştır (Anonim, 2018d). Cumhurbaşkanı Erdoğan 10 Mart 2018'de Antalya'da yaptığı konuşmada, EXPO alanının geleceğinin doğru ş̧ekilde planlanmadığını șu șekilde ifade etmiştir: “Fuar [EXPO] bittikten sonra da ilgili tüm kurum ve kuruluşlarımızın bu projenin ürünlerinin yaşatılması hususunda gayret göstermeleri gerekiyordu. Bunun için gereken formüller üretilmeli ve fuarın bitmesini müteakip devreye alınmalıydı" (Anonim, 2018e).

Mevcut durum itibariyle, EXPO alanındaki yeşil alanları canlandırma çalışmaları hızla devam etmekte olup; ülke bahçeleri etaplara ayrılarak bakımları yapılmakta ve 2019 yılı baharında alanın yeniden yemyeşil hale getirilmesi hedeflenmektedir (Anonim, 2018f). EXPO alanının geleceği ile ilgili farklı öneriler de gündeme gelmiştir. Alana üniversite ve sağlık kampüsü yapılması, Formula 1 yarışlarının getirilmesi gibi fikirler ortaya çıkmıştır. EXPO alanında yer alan bina ve tesislerin kalıcı bir miras unsuru olarak sayılabilmesi için, alanın başlangıçta iyi bir etüt sonucunda seçilmiş olması ve alan mirasının şehrin gelecek vizyonuna entegre edilmiş olması gerekirdi. Ancak, EXPO Antalya Alanının etkinlik sonrası kullanımının henüz netleşmemiş olması, EXPO ve şehrin geleceği arasında planlı bir ilişkinin var olmadığını göstermektedir.

\subsection{Sosyal ve Örgütsel Kapasite}

EXPO ve benzeri organizasyonların mirasları yalnızca yapılı çevre ile sınırlı değildir. Yapılı çevre dışında kalan ve soyut miras olarak kabul edilebilecek unsurlar da organizasyon sonrasında ev sahibi şehirde önemli izler bırakabilir. EXPO ve benzeri organizasyonların ev sahibi șehirde konaklama sektöründe eğitim, sosyal protokolün öğrenilmesi, gönüllü örgütlenmelerin kurulması gibi unsurlar sonucunda sosyal sermayenin gelişimine katkı sağladığı söylenebilir (Wilson, 2018). Ancak sosyal 
sermayenin gelişimi mirası, organizasyon sonrasında devam edememektedir. Bunun önüne geçebilmek için, organize ve eğitimli olan insan ve sosyal sermaye mirası başka projelere yönlendirilmelidir. EXPO Antalya'da organizasyonla birlikte ortaya çıkan sosyal sermayenin etkin kullanılamadığı görülmektedir.

EXPO'nun örgütsel mirası ise bizzat organizasyonun kendisinin yönetimidir (Wilson, 2018). EXPO sona erdiğinde, etkinliğin düzenlenmesinde rol oynayan ve ciddi tecrübe edinen kurumların ve personelin dağıtılması sonucunda organizasyonla elde edilen tüm örgütsel belek ve miras da kaybolmaktadır. EXPO Antalya tecrübesi de bu tespiti doğrulamaktadır. Türkiye'nin ev sahipliği yaptığı ilk EXPO olan 2016 EXPO Antalya, hazırlık sürecinden EXPO'nun kapanışına kadar geçen sürede sürece dahil olan tüm kurum ve kuruluşlar açısından önemli bir deneyim olmuştur. Ancak, EXPO Antalya'nın sona ermesiyle birlikte, süreçte yer alan personel kendi kurumlarındaki görevlerine geri dönmüșlerdir. EXPO Antalya Kanunu'nun 15. maddesinin 2. Fıkrası gereği, EXPO Genel Sekreterliği bünyesinde istihdam edilen diğer personelin iş sözleşmeleri ise 31.12.2016 tarihinde kendiliğinden sona ermiştir. Sonuç olarak, EXPO Antalya'nın tasfiye süreci, kurumsal kültür ve belleği de tasfiye etmiștir.

\section{5. Uluslararası İlişkiler}

Toplamda 54 uluslararası resmi, 4 uluslararası gayri-resmi katılımcı ile 96 ulusal katılımcının bahçelerinin yer aldığı EXPO Antalya, uluslararası ilişkilerin geliştirilmesine olumlu yönde katkı sunmuştur (T.C. Cumhurbaşkanlığı, 2016). EXPO alanında gerçekleştirilen ulusal gün kutlamaları ve katılımcı ülkelerin özel etkinlikleri sayesinde özellikle kültürel anlamda ikili ilişkilerin gelişmesi ve uluslararası işbirliğinin arttırılması imkanları ortaya çıkmıştır. Ulusal günler ve katılımcı ülkelerin özel etkinliklerinin yanı sıra EXPO 2016 Antalya'ya yapılan resmi ziyaretler, ikili ilişkileri güçlendirmede ve uluslararası işbirliğini genişletmede önemli rol oynamıştır. EXPO Antalya temaları kapsamında katılımcı ülkelerin deneyimlerini paylaşmaları ve ortak çözüm üretme kültürünün gelişmesi sağlanmıștır. Ayrıca EXPO 2016 Antalya, teması gereği tarım ve bahçecilikle ilgili önemli konuların gündeme getirildiği bir platform sunarak uluslararası bilgi alışverişi ve deneyim paylaşımına imkan vermiştir. EXPO sayesinde Antalya, bahçe bitkileri alanındaki potansiyelini tüm dünyaya gösterme firsatı bulmuş; sektör temsilcileri ile iş bağlantıları firsatı yakalayarak bu alanda kalkınma ve uluslararası işbirliği imkanlarını artırmıştır. EXPO 2016 Antalya, Antalya ve Türkiye Bahçecilik Sektörünün gelecekteki gelişimine ve uluslararası ilişkilerin sağlamlaştırılmasına katkı sağlamıștır.

Katılımcı birçok ülke stantlarının inşaasında ve stant bedellerinin ödenmesinde Türkiye'nin mali destek sağlamasına karşın katılımcı ülke sayısının beklenenin çok altında kalması; katılımcı ülkelerin bir kısmının EXPO Antalya temasıyla ilgisi olmayan, çiçek yetişmeyen Afrika ülkelerinden oluşması ve EXPO Antalya'ya gelen 4.7 milyona yakın ziyaretçinin sadece yüzde 29'luk kısmının yabancı ziyaretçilerden oluşması organizasyonun uluslararasılaşma vurgusunun zayıflatan önemli unsurlar olarak değerlendirilebilir. Ayrıca uluslararası ziyaretçilerin çoğunlukla yüzde 47'lik oranla, Türk nüfusun yoğun olduğu Almanya'dan gelmiş olması ise başka bir tartışma konusudur. Almanya'dan gelen ziyaretçilerin ne kadarlık bir kısmının Almanya'da yaşayan Türk vatandaşlarından oluştuğu bilinmemektedir. 
Tablo 6. EXPO Antalya Uluslararası Ziyaretçilerin Ülkelere Göre Dağılımı

\begin{tabular}{|l|l|}
\hline Ülke & Yüzdesi \\
\hline Almanya & $\% 47$ \\
\hline Rusya & $\% 22$ \\
\hline Ukrayna & $\% 11$ \\
\hline Hollanda & $\% 9$ \\
\hline Birleşik Krallık & $\% 8$ \\
\hline İsveç & $\% 2$ \\
\hline Diğerleri & $\% 1$ \\
\hline
\end{tabular}

Kaynak: T.C. Cumhurbaşkanlığı, 2016.

\section{Sonuç ve Değerlendirme}

Antalya'nın EXPO tecrübesi olumlu ve olumsuz yönleriyle değerlendirilebilir. Kamu desteğinin sağlanmasını kolaylaştıran ve yatırım süreçlerindeki bürokratik tıkanıklıkları aşmayı sağlayan önemli bir etkinlik olan EXPO sayesinde Antalya'nın turizm ve ulaşım altyapısı büyük ölçüde iyileştirilmiş; şehrin yeşil alan miktarı artmıştır. Toplamda 54 uluslararası resmi, 4 uluslararası gayri-resmi katılımcı ile 96 ulusal katılımcının bahçelerinin yer aldığı EXPO Antalya'nın, uluslararası ilişkilerin geliştirilmesine olumlu yönde katkı sunduğu da söylenebilir. Kalıcı bir alan olarak inşa edilen EXPO Alanı ve içerisinde bulunan binalar ve tesisler, bahçecilik ve tarım sektörünün gelecekteki gelişi için temel oluşturabilecek bir miras olarak görülebilir, ancak bu potansiyelin hayata geçmesini sağlayacak girişimler henüz gerçekleșmiș değildir. Başlangıçtan itibaren EXPO alanının iyi bir etüt sonucunda belirlenmemiş olması ve bu alanın şehrin gelecek vizyonuna bütünleşmiş șekilde planlanmamış olması EXPO alanını olumlu bir miras olmaktan çıkarıp, çözülmesi gereken bire sorun haline getirmiștir. Benzer şekilde EXPO ile elde edilen kurumsal tecrübe ve mirasın organizasyonun sona ermesiyle dağılması da önemli bir kayıp olarak görülmelidir.

Diğer taraftan, EXPO sayesinde hayata geçirilen yatırımların şehrin gelişim yönünün belirlenmesi ve uzun vadeli ihtiyaçların karşılanması konusunda katkı sağlaması beklenirken; EXPO Antalya örneğinde yapılan yatırımların şehrin gelecek hedefleriyle tam olarak örtüştügü söylenemez. Benzer şekilde, EXPO organizasyonunun avantajı olarak görülen atıl tesislerin ortaya çıkmaması durumu EXPO Antalya'da bir avantaja dönüşmemiş; çözülmeye muhtaç önemli bir sorun olarak geleceğe ötelenmiştir. Ayrıca EXPO alanının şehirden uzak olması ve alana erişimde zorluklar yaşanması da EXPO'nun istenilen olumlu mirası bırakamamasına neden olmaktadır. EXPO alanının turistik bir çekim alanına dönüşememiş olmasının bir diğer olumsuz sonucu ise EXPO tecrübesinin sembolik mirası olan EXPO Kulesi'nin sembolik niteliğinin Antalya şehri ile özdeşleşmemiş olmasıdır. Halkla ilişkiler ve tanıtım konusunda yapılan hatalar sonucu EXPO Antalya'nın, yerel halkın etkinliklere aktif katılımını sağlamada da başarılı olduğu söylenemez. Bu süreçte etkinliklere katılımın arttırılmasında önemli rol oynayabilecek olan paydaşların organizasyonun planlanması ve yürütülmesi așamalarına dâhil edilmemiş olması da yüksek katılımlı etkinliklerin gerçekleștirilmesini imkânsız kılmış; organizasyonun başarısını olumsuz yönde etkilemiștir. Organizasyonun planlanması ve yürütülmesi aşamalarında yerel aktörlerden ziyade merkezi yönetimin daha etkin ve karar verici konumda olması sürecin daha hızlı ilerlemesine imkân vermiş; ancak alınan kararların doğruluğunu ve uygulanabilirliğini tartışılır hale getirmiștir. 
EXPO Antalya'nın özellikle soyut miras anlamında istenilen etkiyi gösterememesinde o dönem Türkiye'de meydan gelen iç ve diş siyasi gelișmelerin rolü büyüktür. 24 Kasım 2015 tarihinde Rusya Federasyonu Hava Kuvvetleri'ne ait uçağın sınır ihlali gerçekleştirmesinden dolayı Türk Hava Kuvvetleri tarafından düşürülmesi Rusya ile siyasi, ekonomik ve kültürel ilişkilerimizi kopma noktasına getirmişti (Gürcanlı ve Ergan, 2015). Uçak krizi ile başlayan süreç, özellikle turizm açısından en önemli ortaklarımızdan birisi olan Rusya ile siyasi gerilimi arttırmış ve Rus turistlerin Antalya'ya gelişini etkilemiştir. Bu durum sadece EXPO'yu değil bölgenin tamamının turizmini ve genel ekonomisini ciddi şekilde etkilemiştir. Bunun yanında EXPO alanının ziyarete açık olduğu dönemde gerçekleşen 15 Temmuz darbe girişimi de uluslararası alanda Türkiye'nin itibarını ve güvenli ülke imajını olumsuz etkilemiş; darbe girişimi sonrası dönemde EXPO'nun uluslararası ziyaretçi sayısı ciddi oranda azalmıștır. Bu da 15 Temmuz darbe girişiminin sadece ülkemiz içerisinde değil uluslararası alanda da Türkiye'ye ciddi zararlar doğurduğunu göstermektedir.

Bu gelişmelere ek olarak EXPO Antalya'nın ziyaretçilere açlk olduğu dönemde EXPO alanında herhangi bir güvenlik sorunu kaydedilmemiş olmasına ragmen, ülkemizin diğer bölgelerinde meydana gelen terör olayları da uluslararası kamuoyunda güvenli olmayan Türkiye imajının yayılmasına katkı sağlamıştır. EXPO'yu inşa ederken çok daha büyük hedefleri olduğunu anlatan o dönemki Gıda Tarım ve Hayvancılık Bakanı Faruk Çelik, "Ama bu hedeflere bu anlamda ulaşamadık. Neden ulaşamadığımızı bütün Türkiye biliyor, Antalya biliyor. Maalesef çok büyük talihsizlikler yaşadık. Rusya krizi, turizmle ilgili yaşanan sorunlar, terör olayları ve en önemlisi de 15 Temmuz'daki darbe girişiminden dolayı maalesef ciddi anlamda bu tür aktivitelere katılmada eksiklikler oldu" diyerek EXPO döneminde yaşanan talihsizliklere vurgu yapmıștır (Tarım ve Orman Bakanlığı, 2016).

Kentsel, ekonomik ve kültürel yenilenmenin güçlü katalizörleri olarak görülen EXPOlar, tarihsel süreçte EXPO'ya ev sahipliği yapan şehirlerde stratejik bir nitelik kazanarak yeni kamusal alanların oluşturulmasında, yerel kalkınmanın teşvik edilmesinde ve kente yeni bir dinamizm kazandırılmasında önemli katkılar sunmuștur (Loscertales, 2018). EXPO, planlı bir süreçle yürütülürse kentin gelişimine olumlu katkı sunması mümkün olan önemli avantajları birarada barındıran önemli bir uluslararası organizasyondur. EXPO, geçici bir kutlama olmanın ötesinde kalıcı bir miras odağı ile planlanır ise, ev sahibi şehrin kısa vadeli ihtiyaçlarının karşılanmasının yanı sıra, uzun vadede de şehre hizmet etmeye devam edecektir. EXPO ve benzeri organizasyonların uzun vadede olumlu etkiler ortaya çıkarabilmesinin ön koşulu, ev sahipliğine aday olan şehrin o etkinliği "bir sona ulaştıracak bir araç" olarak görmesidir (Wilson, 2018, s.30). Bunu sağlamanın yolu, șehrin bir gelecek vizyonuna sahip olması ve bu vizyonun șehrin tüm unsurları tarafından kabul edilmiş olmasıdır. Başka bir ifade ile EXPO ve benzeri organizasyonlar, şehrin hâlihazırda var olan gelecek vizyonuna ulaşmanın bir aracı olarak görülmeli; bu organizasyonlar için yapılacak yatırımların şehrin vizyonundan ayrışmaya veya sapmaya sebep olmaması sağlanmalı ve bu sayede organizasyon için yapılan her türlü yatırım ve harcamanın israfa yol açması önlenmelidir.

Geçmiş EXPO deneyimleri göstermiştir ki, EXPOlar zamanla ev sahibi şehirlerde başarılı sonuçlar doğurmaktadır, ancak bu sürecin zaman alması ve başarılı olan kullanımların genellikle başlangıçta planlanan kullanımdan farklılaşıyor olması da dikkate alınmalıdır. Bu kapsamda, kalıcı olarak planlanan EXPO Antalya alanı, geliștirilen altyapısı sayesinde Antalya'nın ve bölgenin gelişiminde uzun vadeli olumlu etkiler yaparma potansiyeline sahiptir. EXPO Antalya alanının kullanımı ile ilgili tartışmaların kamuoyuna açık ve farklı görüşlere imkan verecek şekilde yapılması, başlangıçta eksik kalan planlama sürecindeki yanlışların giderilmesine imkan verebilecektir. Ancak, Antalya örneğinde EXPO sürecinin başlangıçtan itibaren planlı bir şekilde yürütülmemesi, 
ortaya çıkacak sorunların birçoğuna çözüm bulmayı imkansız hale getirmekte; miras odaklı olmayan bir organizasyon süreci sonrasında EXPO Antalya alanına yeni bir amaç bulmak zorlaşmaktadır. Toplamda 130 ülkenin katılımı, 4 milyar Euro gelir elde edilmesi, 30.000 istihdam yaratılması ve 8 milyon kişinin ( 5 milyon yabancı, 3 milyon yerli) ziyaret etmesi hedeflenen 1.8 milyar TL bütçeli EXPO Antalya, birçok uluslararası ve ülke içi yaşanan sorunlardan dolayı beklentilerden uzak bir başarı sergilemiştir (Anonim. 2013). Sonuç olarak 2016 yılı hem Türkiye için hem de Antalya için kötü bir yll olarak tarihe geçmiş, bunun neticesinde de EXPO Antalya'dan beklediği faydaları görememiştir. EXPO Antalya bir eğitim, işbirliği, inovasyonun paylaşımı imkanının olduğu bir etkinlikten ziyade sadece bir eğlence alanı olarak kalmış; Antalya'nın geleceğindeki yeri ve önemi de henüz netleşmemiştir.

\section{KAYNAKÇA}

ANONIM. (2013) Dünya Botanik EXPO'su “Çiçek ve Çocuk” Temasıyla 2016'da Antalya'da Düzenleniyor. Ekonomik Forum Dergisi. Türkiye Odalar ve Borsalar Birliği, s.28-33.

BABACAN, N. (2016) Expo'nun başına gelmeyen kalmadı. Hurriyet.com.tr, 24 Eylül 2016. http://www.hurriyet.com.tr/exponun-basina-gelmeyen-kalmadi-40230715

Türkiye Cumhuriyeti Cumhurbaşkanlığı. (2016). EXPO Antalya Sonuç Raporu.

EXPO Antalya Web Sayfası. http://www.expo2016antalya.org.tr

LOSCERTALES, V. G. (2018), Preface. Bureau International des Expositions (BIE) Bulletin 2018.

Uluslararası Sergiler Bürosu (BIE). (10.02.2017a) Resmi internet sayfası. Erişim tarihi: 10.02.2017, http://www.bie-paris.org

ANONIM. (30.10.2017a). EXPO Kulesi, dünyanın en iyi kültürel yapısı seçildi.

Haberantalya internet sayfası. Erişim tarihi: 10.11.2017,

https://www.haberantalya.com/expo-kulesi-dunyanin-en-iyi-kulturel-yapisisecildi/425648

ANONIM. (11.05.2016a) "EXPO 1500 Kişi İçin Yapılmadı". Turizm gazetesi internet sayfası. Erişim tarihi: 12.11.2017, http://www.turizmgazetesi.com/news.aspx?Id=80391

ANONIM. (16.05.2016b) "Turizmcinin EXPO Umudu Suya Düştü". Turizm gazetesi internet sayfası. Erişim tarihi: 12.11.2017,

http://www.turizmgazetesi.com/news.aspx?Id=80426

ANONIM. (08.06.2016c) "Skandallari Olmasa Antalya Expo'yu Bilen Yok". Turizm gazetesi internet sayfasi. Erişim tarihi: 12.11.2017,

http://www.turizmgazetesi.com/news.aspx?Id=80644

ANONIM. (22.01.2015a) "EXPO 2016 Genel Sekreteri İstifa Etti". Turizm gazetesi internet sayfası. Erişim tarihi: 12.11.2017,

http://www.turizmgazetesi.com/news.aspx?Id=75901

ANONIM. (29.04.2017b) "Bakan Çelik: "EXPO Alanı Kamu Tarafindan Memur Bakışıyla Yönetilemez"'. Milliyet gazetesi internet sayfası. Erişim tarihi: 12.11.2017, http://www.milliyet.com.tr/bakan-celik-expo-alani-kamu-tarafindan-antalyayerelhaber-2008181/

ANONIM. (03.05.2017c) "EXPO 2016 Antalya'nın Geleceği". Gazete Bir internet sayfası. Erişim tarihi: 12.11.2017, https://www.gazetebir.com.tr/haber/expo-2016antalya-nin-gelecegi/

ANONIM. (18.01.2018a) "EXPO'ya yeni planlama" Sabah gazetesi internet sayfasl. Erişim tarihi: 21.05.2018, https://www.sabah.com.tr/akdeniz/2018/01/18/expoyayeni-planlama 
Tuna Batuhan, “Antalya'nın EXPO 2016 Tecrübesi ve Organizasyon Mirasının Değerlendirilmesi”, İstanbul Gelişim Üniversitesi Sosyal Bilimler Dergisi, 7 (2), Ekim 2020, ss. 281-298.

ANONIM. (28.06.2018b) "1.8 milyar TL harcanan virane haldeki EXPO alanı, yeniden canlanacak" Hürriyet gazetesi internet sayfası. Erişim tarihi: 15.08.2018, http://www.hurriyet.com.tr/1-8-milyar-tl-harcanan-virane-haldeki-expo-alan$\underline{40879902}$

ANONIM. (19.07.2018c) "İşlevini bitirdi" algısı oluşan EXPO 2016 alanı yeniden canlandırllıyor" Yeni Alanya gazetesi internet sayfası. Erişim tarihi: 15.08.2018, https://www.yenialanya.com/ekonomi/islevini-bitirdi-algisi-olusan-expo-2016-alaniyeniden-canlandiriliyor-h332496.html

ANONIM. (29.03.2018d) "1.8 milyar lira harcanan EXPO çürüyor" Haberantalya internet sayfası. Erişim tarihi: 15.08.2018, https://www.haberantalya.com/1-8-milyarlira-harcanan-expo-curuyor/430997/

ANONiM. (10.03.2018e) "Cumhurbaşkanı Erdoğan Antalya'da flaş açıklamalar" Sabah gazetesi internet sayfasl. Erişim tarihi: 15.08.2018,

https://www.sabah.com.tr/gundem/2018/03/11/cumhurbaskani-erdogan-antalyada

ANONIM. (05.10.2018f) "Antalya EXPO 2016 Canlanıyor" Ayylldız Toros gazetesi internet sayfası. Erişim tarihi: 15.10.2018, http://www.ayyildizgazetesi.com/haber44056-Antalya-Expo-2016-Canlaniyor.html; https://www.sabah.com.tr/akdeniz/2018/10/06/expo-canlaniyor

GÜRCANLI, Z. \& ERGAN, U. (24.11.2015) "Suriye sınırında uçak düşürüldü" Hürriyet gazetesi internet sayfasl. Erişim tarihi: 12.11.2017,

http://www.hurriyet.com.tr/gundem/suriye-sinirinda-ucak-dusuruldu-40017924

Özelleştirme İdaresi Başkanlığı. (08.11.2017) "EXPO 2016 Antalya Uluslararası Sergi ve Fuar Alanının Özelleștirilmesi". Özelleștirme İdaresi Başkanlığı internet sayfası. Erişim tarihi: 12.11.2017, http://www.oib.gov.tr/T\%C3\%BCrk\%C3\%A7e/Sayfalar/Galerili Sayfa/EXPO 2016 Ant alya Uluslararas\%C4\%B1 Sergi ve Fuar Alan\%C4\%B1n\%C4\%B1n_\%C3\%96zelle\%C5 \%9Ftirilmesi/1510126825.html

T.C. TARIM VE ORMAN BAKANLIĞI (29.10.2016) "EXPO alanı, ülke turizmine hizmetini sunmaya devam edecek" T.C. Tarım ve Orman Bakanliğı internet sayfası. Erişim tarihi: 10.09.2017, https://www.tarimorman.gov.tr/Haber/1048/expo-alani-ulketurizmine-hizmetini-sunmaya-devam-edecek

ULUSLARARASI SERGILER BÜROSU (BIE). (20.03.2017b) BIE activity. Erişim tarihi: 10.02.2017, https://www.BIE-paris.org/site/en/news-announcements/BIEactivity?start $=60$

WILSON, M. (2018), Expos: Temporary Events with Lasting Impacts, Bureau International des Expositions (BIE) Bulletin 2018.

\section{Summary}

EXPO Antalya 2016 presented an cultural and visual feast to the visitors between April 23rd-October 30th. Antalya's EXPO experience can be evaluated with its positive and negative aspects. Thanks to EXPO, which is an important activity that facilitates the provision of public support and overcomes bureaucratic bottlenecks in investment processes, Antalya's tourism and transportation infrastructure has been greatly improved; the amount of green space in the city has increased. EXPO Antalya, which hosted a total of 54 international official, 4 international informal and 96 national participant gardens, contributed positively to the development of international relations. The EXPO Area, built as a permanent site, and the buildings and facilities within it can be seen as a legacy that can be the basis for the future development of the horticultural and agricultural sector, but initiatives to realize this potential have not yet been realized. 
On the other hand, the investments realized through EXPO are expected to contribute to determining the development direction of the city and meeting the long-term needs; it cannot be said that the investments made in the case of EXPO Antalya fully coincide with the future goals of the city. Similarly, the absence of idle facilities, seen as the advantage of the EXPO organization, has not turned into an advantage at EXPO Antalya; it has been postponed to the future as an important problem that needs to be solved. Furthermore, the EXPO area is far from the city and difficulties in accessing the area cause the EXPO to leave the desired positive heritage. Another negative result of the fact that the EXPO area could not be turned into a touristic attraction area is that the symbolic quality of EXPO Tower, which is the symbolic heritage of EXPO experience, is not identified with the city of Antalya. As a result of mistakes made in public relations and promotion, EXPO Antalya cannot be said to be successful in ensuring the active participation of local people in the activities. The fact that central government was more effective and decision-making rather than local actors in the planning and execution stages of the organization enabled the process to proceed faster; however, the accuracy and applicability of the decisions taken have been debatable.

EXPO Antalya did not show the desired effect especially in terms of intangible heritage, mainly because of the negative internal and external political developments occurred during that time period in Turkey. On November 4, 2015, Russian plane crashed by the Turkish Air Force due to border violation and Turkey's political, economic and cultural relations with Russia brought to the breaking point (Gürcanlı ve Ergan, 2015). The process that started with the plane crisis increased political tensions between Turkey and Russia, one of Turkey's most important partners in terms of tourism, and influenced the arrival of Russian tourists to Antalya. This has affected not only the EXPO event, but also the tourism and the general economy of the whole region. Besides, the July 15 coup attempt, which occurred during the time period when the EXPO area was open to visitors, had a negative impact on Turkey's reputation and "secure country image" in the international arena. In addition to all these events, although no security issues have been recorded in the EXPO area, terrorist incidents occurred in other parts of the country has contributed to the spread of "non-secure Turkey" image in the international community.

The permanently planned EXPO Antalya area has the potential to have long-term positive effects on the development of Antalya and the region thanks to its developed infrastructure. However, in the case of Antalya, the fact that the EXPO process is not carried out in a planned way from the beginning makes it impossible to find solutions to many of the problems that will arise; after a non-heritage-oriented organization process, it becomes difficult to find a new purpose in EXPO Antalya area. EXPO Antalya, with a total budget of 1.8 billion TL, which is expected to be attended by 130 countries in total, 4 billion Euro income, 30,000 jobs and 8 million people (5 million foreigners, 3 million domestic), was unsuccessful beyond expectations due to many international and domestic problems. As a result, 2016 was a bad year for both Turkey and Antalya history and EXPO Antalya has not achieved the expected benefits. EXPO Antalya has remained a mere entertainment area rather than an activity where education, collaboration, innovation can be shared and importance of EXPO for Antalya in the future has not yet become clear yet. 